\title{
Review
}

\section{Rediscovering Political Friendship. Aristotle's Theory and Modern Identity, Community, and Equality}

\author{
Paul W. Ludwig \\ Cambridge University Press, Cambridge, 2020, 362pp. \\ ISBN: 978-1107022966
}

Contemporary Political Theory (2022) 21, S59-S62. https://doi.org/10.1057/s41296020-00442-0; published online 21 September 2020

One might be forgiven for believing, upon opening this book, that the early 1980s debate between liberals and communitarians is back. A feeling of nostalgia almost arises for the times of that dispute-one that, for those like me who received higher education in the new millennium, has quasi-legendary undertones. Meanwhile, history had ended, and liberalism had triumphed. But a quick look at political developments since the second half of the past decade, with its surge of successful nationalistic and identity-based claims, suggests that there is fertile ground for a new wave of communitarian thought. With this political context in mind, Ludwig seeks inspiration from classical texts, and the final product is a fascinating, authoritative, and complex volume. The book, however, is not the revival of a debate but rather a reconciliation. Rediscovering Political Friendship attempts the reconstruction of this concept-usually thought of as a stronghold of communitarian ethics-as a supplement for 'liberalism's attempts to negotiate the real difficulties pointed out by liberalism's opponents' (p. 39). This dialogue between ancient texts and the politics of modernity brings to mind masterpieces of the 1980s, such as Walzer's Exodus and Revolution (1985) or Nussbaum's The Fragility of Goodness (1986). Ludwig draws on classic texts of political thought from Plato to Hegel and from Tocqueville to Walzer to reflect on contemporary politics and about the world as it should be.

The book's epigraph quotes Cicero: 'Our nature is to be in a sort of league (societas) with everyone-the closer the person, the stronger it becomes (maior autem ut quisque proxime accederet)'. This quote really expresses, and powerfully so, the terms in which Ludwig presents his argument. The key tenet of the book is that 'political friendship', a direct translation of Aristotle's politike philia, is a feeling which must be studied carefully, and indeed elevated-or countered when it cannot be elevated-by political theory. Granted, friendship occupies a special

(c) 2020 Springer Nature Limited. 1470-8914 Contemporary Political Theory Vol. 21, S2, S59-S62 
place in political theory, but it is Ludwig's contention that the last wave of communitarian theorists failed to grasp the importance of getting the theoretical foundations of friendship right. To supply such a foundation, Ludwig draws inspiration from the Stagirite.

Ludwig's key contention is that preference for one's neighbour over the stranger, for the fellow citizen over the foreigner, can be justified. We know from MacIntyre's (1981, p. 189) seminal analysis that the relegation of friendship to a merely private phenomenon is a (criticisable) artefact of liberalism. Ludwig, too, insists on this point and adds that it can be reconciled with a liberal understanding of politics. His argument proceeds as follows: the basic Aristotelian insight that there exists a political friendship describes a truth that cannot be ignored. We bond with people with whom we are affiliated, and an often-neglected form of such affiliation is the agreement we share with fellow citizens about the basics of a political system (what Ludwig refers to as 'society-wide friendship'). To be sure, affinity for fellow citizens can be overridden by other bonds, but it exists, and it is not merely patriotism. The view that citizens of a country will agree on the basics of their political system is, however, is too optimistic, and I will argue later that its central role in Ludwig's argument is not entirely warranted.

Aristotle speaks of a plurality of political friendships as analogous to a form of love and with various geneses: Aristotle's affirmation that thumos (passion, sometimes downright anger) is the origin of to philetikon (affectionateness) leads Ludwig on an interesting reflection on the connection between anger and friendship. Even today, associations of citizens have various scales and disparate origins. Within a political system - that is, within society-wide friendship -, there exist other communities, each one sharing its own philia. A bond arising out of fear, for example within an ethnic minority, can be 'self-assertive and defensive' (p. 73). By contrast, bonding can also be motivated by utility: an association where members join for utility is “"our” version of civic friendship' (p. 325 and ch. 4). Ludwig uses this psychology of associations as a springboard to show that liberalism and political friendship are far from irreconcilable: liberal societies can afford to recognise certain bonds of philia. To substantiate this claim, each chapter examines how political friendship can be acknowledged in liberal societies. Concepts such as recognition of identity and love for others can be accommodated within a liberal paradigm, thanks to the insight offered by a theoretical, Aristotelian analysis of political friendship.

Even though Ludwig does not put it in these terms, the central question of the book is how to organise the various philiai within a system: which ones ought to be recognised as worthy? Is it possible to rank them so as to manage conflicting interests? If so, who decides how? The book offers some answers, particularly by commenting on a set of hot topics in contemporary political discourse: identity politics, group rights, group membership, social policy, and common goods. The book offers policy recommendations which are both scattered through the volume 
and articulated more systematically in a concluding chapter. At times, Ludwig's attempt to reconcile liberal-progressive stances with political friendship has a whiff of resignation, for instance when he asks, 'Why not contribute to ushering in a good-or at least decent-version of what will exist whether we like it or not?'(p. 65 n. 8). Nevertheless, there is much with which to agree in the book. As Ludwig convincingly argues, some of the policies, which are currently enacted or being debated, such as speech-restrictions, are questionable because they are self-defying (so, repressing certain groups only makes them stronger p. 390). The same might apply to legislation on fake news, but this rarely dawns on politicians.

The book intervenes in a range of debates, and given its ambition and scope, critics will find targets to attack. For instance, there is relatively little attention to relevant scholarship on collective action and rational choice theory. Moreover, the book is squarely situated within the context of U.S. politics and its preoccupations. Its practical implications are only of indirect relevance for other political systems. Further, the acknowledgment that, for Aristotle, there are various forms of friendship and that society-wide friendship should neither 'absorb' nor 'eliminate' the bonds between communities and society, could be more central to the analysis. The claim that citizens agree on the basics of a political system is too optimistic and easily disproved on empirical grounds. Most importantly, however, Ludwig's notion of society-wide friendship is not an aspirational goal but rather one example of a possible form of political friendships within a society. Normatively, its desirability remains to be demonstrated. On the one hand, society-wide friendship may not be desirable, because it is not necessary. Ludwig does not justify convincingly why society, as opposed to some other community, is to be privileged as a category of political friendship. It is just an ideal type, since a society is a community that has only partially overlapping membership with other groups. Its positive causal effect over other forms of friendship remains to be demonstrated. On the other hand, society-wide friendship may be undesirable for reasons of scale. In light of the book's epigraph, one might wonder how the mere fact of one's nationality can create a meaningful bond with people one does not know and with whom there is no proximity? Ludwig offers a thoughtful defence (sections $7.4 \mathrm{ff}$ ), considering, for instance, the bonds created by social media. But especially if we admit that, for example, Instagram followers can be civic friends, the question remains why the relevant boundaries of a civic friendship community should be the borders of modern states. Finally, more needs to be said about identity politics as motivated by amour-propre. This topic is merely implied in the book, even though chapter 3 is dedicated to a partially related phenomenon, namely self-interest and the problem of collective action. Amour-propre may be a strong motivation, regardless of the reasons individuals and groups endorse to justify a claim to affiliation, recognition, or identity. As La Rochefoucauld (1871, p. 83) argued, 'What men term friendship is merely a partnership (une société) with a collection of reciprocal interests, and an exchange of favours - in fact it is but a trade in which

(C) 2020 Springer Nature Limited. 1470-8914 Contemporary Political Theory $\quad$ Vol. 21, S2, S59-S62 S61 
self-love always expects to gain something'. An inquiry into when this might be the case might contribute meaningfully to our understanding of political friendship and group recognition, without thereby condemning them.

There is very much to commend in this book. Rediscovering Political Friendship is a masterful exposition of normative political theory and the kind of work that evinces decades of fruitful study. Its arguments require time to unpack, and it is definitely worth reading not only for specialists, but also for anyone interested in the organisation of society.

\section{References}

MacIntyre, A. (1981). After Virtue. A Study in Moral Theory. Notre Dame, IN: Notre Dame University Press.

Nussbaum, M. (1986). The Fragility of Goodness. Luck and Ethics in Greek Tragedy and Philosophy. Cambridge, UK: Cambridge University Press.

Rochefocauld, 1871. Reflections. London: Simpson Low, Son, and Marston

Walzer, M. (1985). Exodus and Revolution. New York, NY: Basic Books.

Publisher's Note Springer Nature remains neutral with regard to jurisdictional claims in published maps and institutional affiliations.

Luigi Lonardo

University College Cork, Cork T12 YN60, Ireland luigi.lonardo@hotmail.com 